\title{
SUBSURFACE UTILITY NETWORK CADASTRE PROPOSAL, BASED ON LADM (ISO / FDIS 19152)
}

Wedja de Oliveira Silva ${ }^{1}$ - ORCID: 0000-0002-6048-9472

Andrea Flávia Tenório Carneiro ${ }^{1}$ - ORCID: 0000-0002-2445-2330

\author{
${ }^{1}$ Universidade Federal de Pernambuco Centro de Tecnologia e Geociências - CTG, Departamento de Engenharia \\ Cartográfica, Recife - PE. Av. Acadêmico Hélio Ramos, s/n - Cidade Universitária, CEP: 50740-530 Recife - PE \\ E-mail: oliveirawedja@gmail.com \\ E-mail: andreaftenorio@gmail.com
}

Received in 05 ${ }^{\text {th }}$ September 2019

Accepted in $23^{\text {rd }}$ Mars 2020

\begin{abstract}
:
The increasing usage of the space above and underneath the land surface brings up the need of controlling its occupation. The localization of the infrastructure underground network is a major challenge, and for most of the countries, this information is not yet available or not easy to access. At this juncture, the cadastre of the network location is of fundamental importance for the water management supply systems. ISO 19152 from 2012 - Land Administration Domain Model (LADM) - addresses the standardization and integration of common features of cadastre systems in a simple way, and may be applied to several aspects of land administration. Within this context, this research aims to develop a model of subsurface water utility networks, based on the standard proposed by LADM. The implementation of the model suggested by ISO 19152 was tested using the COMPESA cadastre of the water utility network as a study case. The modernization and the technological advances adopted by the company facilitated the understanding of the geographical database underlying structure and its adaptation to the international standard. The modeling was produced using UML language, and DBDesigner for the physical implementation, executed in connection with PostgreSQL/PostGIS and QGIS, was applied.
\end{abstract}

Keywords: Infrastructure networks cadastre; LADM; Cadastral modeling.

How to cite this article: SILVA, W. O.; CARNEIRO, A. F. T. Subsurface utility network cadastre proposal, based on LADM (ISO/FDIS 19152). Bulletin of Geodetic Sciences. 26(2): e2020006, 2020 


\section{Introduction}

The main purpose of land cadastre is to describe the relationships between people and the land through rights, restrictions and responsibilities there are between them. Considering these relations not only refer to the surface of the land, but also involve the air space and the subsoil, it is necessary to consider a third dimensional cadastral system, especially when the use of these spaces becomes more intensive. The spaces beneath the surface, formerly occupied mainly by water, sewage and gas networks, are now also shared with power, telephony, TV, fiber optic networks. etc.

Insufficient information on the location and depth of infrastructure networks results in problems that affect the surface and subsurface of constructions planning, and possible damage to networks during excavation operations, with significant financial losses, as well as tragic accidents (Döner et al., 2011).

Hashim et al. (2010) points out that most of the infrastructure networks are installed in the streets and roads at a depth of up to $2 \mathrm{~m}$, which causes saturation of the occupation of this space, which has been more and more disputed lately. An information system developed for the administration of subsurface utility networks needs to have different characteristics, due to the need of aggregating the information concerning the depths or differences in dimension related to occupations above the surface (e.g. buildings). The Land Administration Domain Model (LADM), proposed by ISO 19152, addresses the unification and integration of common features of cadastral systems in a simple way, aiming to facilitate the implementation of land cadastre by governmental and private bodies, within an international standard.

Generally in Brazil the maps of the so-called technical cadastres from the infrastructure companies are made in 2D, and in case of the underground infrastructure networks, data on the depth of the equipment of these networks are included. Often the deployment of the networks is documented through isolated projects that are not integrated into the cartographic system. In addition, although there are technical norms that set standards such as the depth of each type of network, in some cases the design is changed due to conditions at the site of implementation, and these changes are not documented.

In this context, this research tested the application of the standards proposed by ISO 19152 to the case of a cadastral model for subsurface utility networks. The developed modeling was tested through a study case using the database of water distribution network systems of Companhia Pernambucana de Saneamento - COMPESA.

\section{Water Supply Systems}

The usage and occupation of the soil cover several urban utilitarian activities, and one of the applications which is essential for humans well-being, is the distribution of drinking water. The Agência Nacional de Águas - ANA is responsible for the management of water resources in the country, following the fundamentals, guidelines and instruments of the Política Nacional de Recursos Hídricos developed in conjunction with public and private agency members of the Sistema Nacional de Gerenciamento de Recursos Hídricos.

A water supply system is characterized by the capturing of natural water and its subsequent treatment so that it can be supplied to the population. The distribution network represents the final phase of a water supply system. Such network is characterized by a set of pipes, connections and special parts, intended to provide water in sufficient quantity, quality and pressure to supply different places of consumption.

Water networks and the elements that make them are represented by lines and points, in a two-dimensional plane. There has been research about the visualization of the networks using a third dimensional one, getting closer 
to the real situation (Du and Zlatanova (2011), Balogun et al (2011), Guerrero et al (2013)).

Brazilian standards that establish the guidelines for the elaboration and implementation of supply systems and water distribution networks, determine what is necessary for the process of elaborating water supply projects from conception to final destination. Among the various existing standards the ones which relate directly to the modeling proposed in this research are highlighted in Table 1.

Table 1: Standards

\begin{tabular}{|c|c|c|c|}
\hline \multirow[t]{2}{*}{ STANDARDS } & $\begin{array}{l}\text { NBR 12.218/94 } \\
\text { (Associação Brasileira de } \\
\text { Normas Técnicas, 1994) }\end{array}$ & $\begin{array}{l}\text { NBR 12.266/92 } \\
\text { (Associação Brasileira de } \\
\text { Normas Técnicas, 1992a) }\end{array}$ & $\begin{array}{l}\text { NBR 12.586/92 (Associação } \\
\text { Brasileira de Normas Técnicas, } \\
\text { 1992b) }\end{array}$ \\
\hline & $\begin{array}{l}\text { Water distribution network } \\
\text { project for public supply }\end{array}$ & $\begin{array}{l}\text { Design and execution of } \\
\text { ditches for laying of water } \\
\text { and sewage pipes }\end{array}$ & Cadastre of water supply System \\
\hline \multirow[t]{8}{*}{ GUIDELINES } & Dimensioning of the pipes & Depth of settlement & \multirow{3}{*}{$\begin{array}{l}\text { Support the development of } \\
\text { studies and related projects } \\
\text { (topographic Support, Field } \\
\text { survey, cadastral plan of the } \\
\text { units, plan and profile of the } \\
\text { conductors). }\end{array}$} \\
\hline & Tracings of conduits & Pipe Diameter and Slope & \\
\hline & Main pipes: closed circuits & \multirow[t]{2}{*}{$\begin{array}{l}\text { Number of pipes: single or } \\
\text { double net }\end{array}$} & \\
\hline & Secondary pipes: mesh network & & \multirow{2}{*}{$\begin{array}{l}\text { Assist in the operation and } \\
\text { maintenance of the system units. }\end{array}$} \\
\hline & Network Measurement Sectors & Type of pavement & \\
\hline & Delimitation of pressure zones & Interferences & \multirow{3}{*}{$\begin{array}{l}\text { Enable the centralization of } \\
\text { system information: speed up the } \\
\text { collection of data, constitute a } \\
\text { single database for all interested } \\
\text { parties, facilitate updating the } \\
\text { register. }\end{array}$} \\
\hline & Hydrant & \multirow{2}{*}{$\begin{array}{l}\text { Positioning of the pipe: } \\
\text { carriageway bed or public } \\
\text { road }\end{array}$} & \\
\hline & Perimeter of refillable area & & \\
\hline
\end{tabular}

The dimensioning of the pipes is regulated by NBR 12.218 (Associação Brasileira de Normas Técnicas, 1994), which establishes the pipe diameters in the preparation of the water distribution network design, as well as the tracing of the main and secondary conduits. The depth of settlement of the pipes is determined in NBR 12.266 (Associação Brasileira de Normas Técnicas, 1992a), which determines that the positioning of the trenches must be done in the project according to the municipal standards of occupation of the various lanes of the public highway.

The NBR 12.586 (Associação Brasileira de Normas Técnicas, 1992b) addresses the procedures related to the network cadastre, defining it as "the set of trustworthy information of an installation, presented through texts and graphical representations in a convenient scale". The standard also provides definitions regarding the elements that constitute a water supply system, such as abstraction, lift station, water treatment plant, reservoir, pipeline, distribution network and property extension.

Using geoprocessing environments, updating network information (such as location and depth) it becomes faster and more accurate, facilitating data interoperability with other utilities that share the same space, whether at the surface or subsurface.

\subsection{LADM - Land Administration Domain Model - From ISO 19152}

The Land Administration Domain Model (LADM) was defined by ISO/FDIS 19152: 2012, which is an international standard for land management. This legislation establishes the development of software applications 
and accelerates the implementation of land management systems that support sustainable development.

The LADM comprises the basic components related to land management information above and below the surface. The standard provides an abstract and conceptual model, structured in three basic packages - Party, Administrative and Spatial unit - and one sub-package - Surveying and Representation.

The relations between these basic packages are represented in Figure 1.

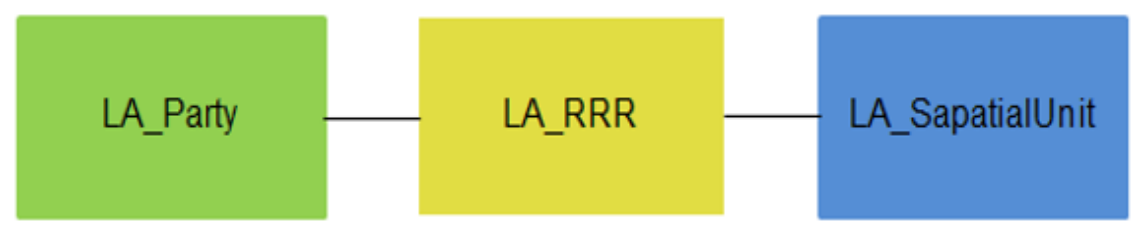

Source: adapted from ISO 19152, 2012.

Figure 1: List of basic LADM packages.

ISO 19152 / 12 was structured, explained and exemplified by several authors, such as e.g.: Cámara et al (2010), Lemmen (2012), Oosterom et al (2013), Lemmen e Oosterom (2013), Lemmen et al (2014), Paulsson e Paasch (2015).

Utility networks are inserted into LADM through the LA_LegalSpaceUtilityNetwork class, which is associated with external classes for public service networks. This model gives an accurate idea of the relationship between the physical and legal representations of a real object. (DONER et al, 2011).

The localization of subsurface utility networks is a major challenge, and for most of the countries, this information is not yet available nor easy to access. Even in 2D cadastral maps, subsurface networks are rarely represented. According to Pouliot et al. (2015), this situation varies from country to country, and they mention Switzerland as an example of a country where there is a cadastre officer assigned to work especially with this type of networks. In addition, the parcel position is partially available in 2D, with optional height attribute. In Australia, utility networks are presented on 2D maps.

Pouliot and Girard (2016a) conclude that network segmentation rules should not depend on parcel boundaries, but there should be a number which links the parcel and the network.

Radulovic et. al. (2019) present the results of a research that aimed to develop a unified information system of both the real estate and utility network cadastre in Serbia, which is a requirement of the The Law on State Survey and Cadastre of Serbia. This new cadastral system should be based on a new data model that will support better cadastral (and utility) data management, provide better integrity of the data by establishing relations among the data, and enable a more advanced search of the data. The obtained extended Serbian LADM country profile would enable full implementation of the Law and faster and more efficient functioning of the unified information system.

Yan et. al. (2019) proposed an integration model for the case of Singapore, using the LADM is a link to build a relationship between the geometric information of utility network and land administration management. The research provides a case study of 3D utility mapping workflow from data capture to data modelling, that includes two main tasks: the conceptual design of LADM-based 3D underground utility data model. In order to connect 3D modelling of underground utility to land administration, some of the attributes and values of this data model are inherited from Singapore cadastral data model and LADM (ISO 19152); and based on the 3D underground utility data model, a consolidated underground utility database was developed. In this database, the underground utility data was integrated with cadastral data. 


\subsection{Modeling of Cadastre of Water Utility Networks in Accordance With ISO 19152}

The modeling of cadastre in the standard ISO 19152 / 12 - LADM (ISO/FDIS/TC211, 2012) - occurs through UML class diagrams. The UML - Unified Modeling Language - is a visual language used to model software based on the object orientation paradigm (GUEDES, 2011).

One of the most usual models for spatial data modeling is the OMT-G (Object-Modeling Technique for Geographic Applications) that starts from the primitives defined for the UML class diagram (Rational Software Corporation, 1997).

The OMT-G model is based on three main concepts: classes, relationships, and spatial integrity constraints. The steps followed to execute the modeling are presented in Figure 2.

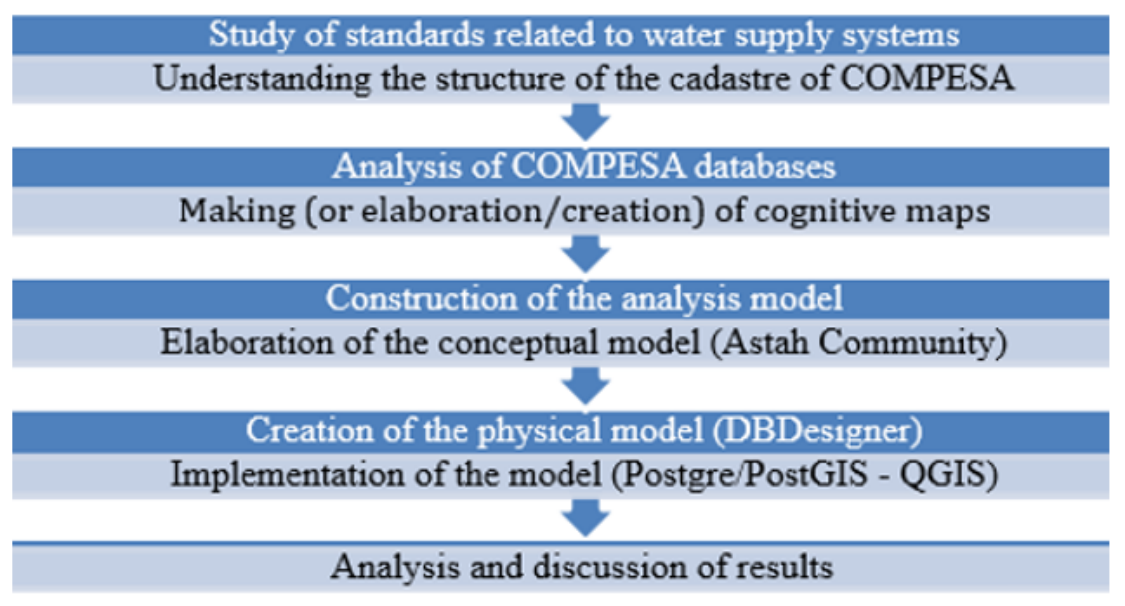

Figure 2: Stages of research development.

In order to understand the structure of the water supply networks cadastre, a study of the Companhia Pernambucana de Saneamento - COMPESA was perfomed, which has a digital and active database, and to which the authors had access for the development of this research.

\section{Modeling the Cadastre of Companhia Pernambucana de Saneamento - COMPESA}

COMPESA is the agency responsible for water supply and sewage services in the State of Pernambuco. For the development of this research, the technical and commercial cadastre of the company was analyzed and modeled, according to LADM standards. It should be noted that the term "cadastre" refers to the company's customer and cadastre service, and it is different from the territorial cadastre term, which seeks to describe the territory as a whole, relating land and people through rights, restrictions, and responsibilities.

The commercial cadastre of COMPESA deals with records of water connections. It is defined as a water connection: the hydrometer, or the object that monitors the amount of water consumed by the user. A water connection is the smallest cadastre unit of COMPESA, to which is assigned a cadastre number that contains the data relating to the customer's cadastre (relation: a situation of water connection and customer).

The technical cadastre understands how water connects to the hydrometer, equipment that records the 
consumption of water. Its cadastre is totally focused on the structure of the network, its components (pipes, parts, pumps, hydrants, etc.), location, and distribution in space (relation: physical object and space).

In COMPESA there are two active databases, one is geographical (GISCOMP) and the other one is alphanumerical (GSAN). O GSAN - Gestão de Serviços de Saneamento - is an integrated service management system. It is an alphanumerical database. The COMPESA GIS Web platform is called GISCOMP, and gives restricted access to employees who work directly with the system. The Geographic Databases used is multi-user Geodatabase (GDB) comprised of ArcSDE. The geoprocessing program used is ArcGIS and the SGBD is SQL Server.

Based on this information, it was possible to elaborate a conceptual map, allowing a better understanding of the database under analysis and facilitating LADM modeling. Details on the structure of the system data can be seen in Silva (2017).

\subsection{The Modeling of COMPESA Cadastre in Accordance With LADM}

The software Astah Community performed conceptual modeling by the UML diagrams that characterize the LADM model. Following the original LADM class configuring pattern, each newly created class is prefixed with "LA" in its name. Within the classes and packages that make up the structure, the first-class modeled and analyzed was the LA_Party, which contains the attributes: exPID; name; pID; role and type, which represent, respectively: the identifier of an external instance; the name; the identifier; the role of an instance in updating data and maintaining information, and the type of instance.

The Party package represents the Client, and the attributes of the class are the client code; the name of the customer; the customer's CPF; the type of person; and the type of customer. The attributes of the class LA_RRR were extracted from the information contained in figure 03, in which:

- LA_Responsability is represented by the "account expiration day";

- LA_Right the right to use water identified by the customer's code; and

- LA_Restriction represented by the attribute "blocked by negativity".

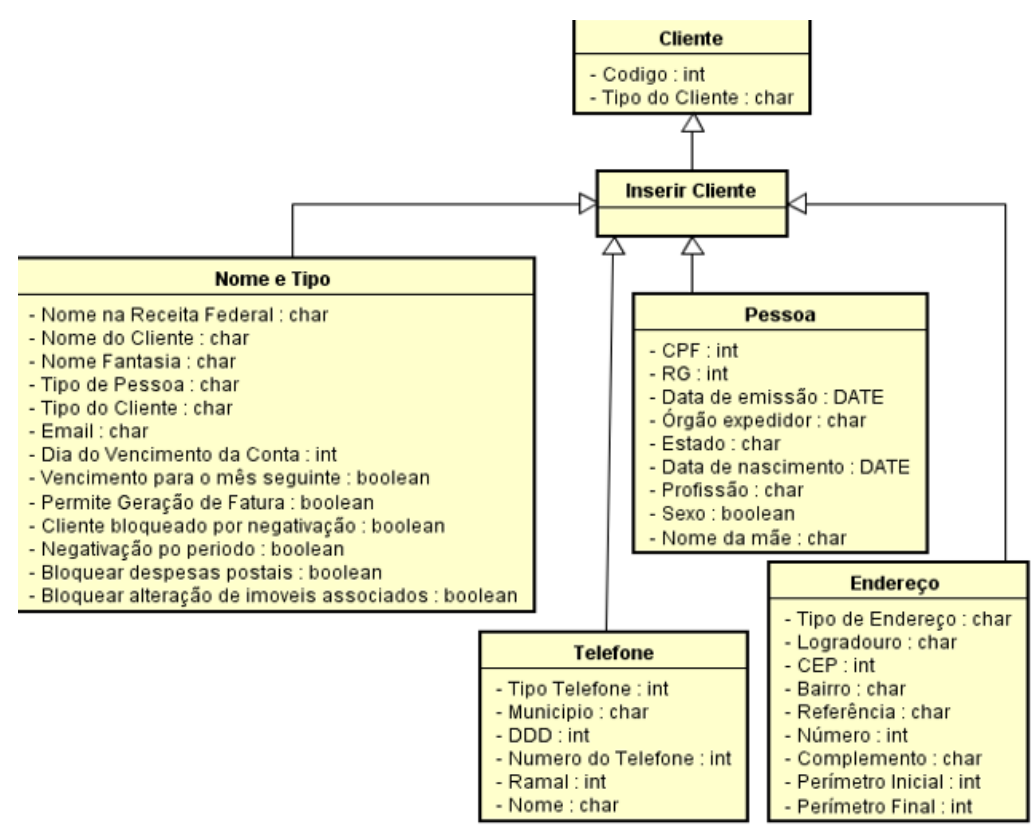

Figure 3: Party package analysis model. 
The water connection is stored by the LA_SpatialUnit class characterizes the spatial unit. The geometries of the lots, blocks and networks are stored in the package classes LA_BoundaryFaceString, La_BoundaryFace and LA_Point In which lots can be represented through the LA_BoundaryFaceString class, through the "Geometry: GM_Multiline" attribute; and the Hydrometers (measuring instrument that characterizes the water connection), represented by LA_Point class.

Within the SpatialUnit package, the class LA_LegalSpaceUtilityNetwork is stored, which deals directly with the utility network. The class was modeled according to the LADM standard and matches the network of this model of analysis. Figure 4 shows how the modeling of the class with its attributes behaves.

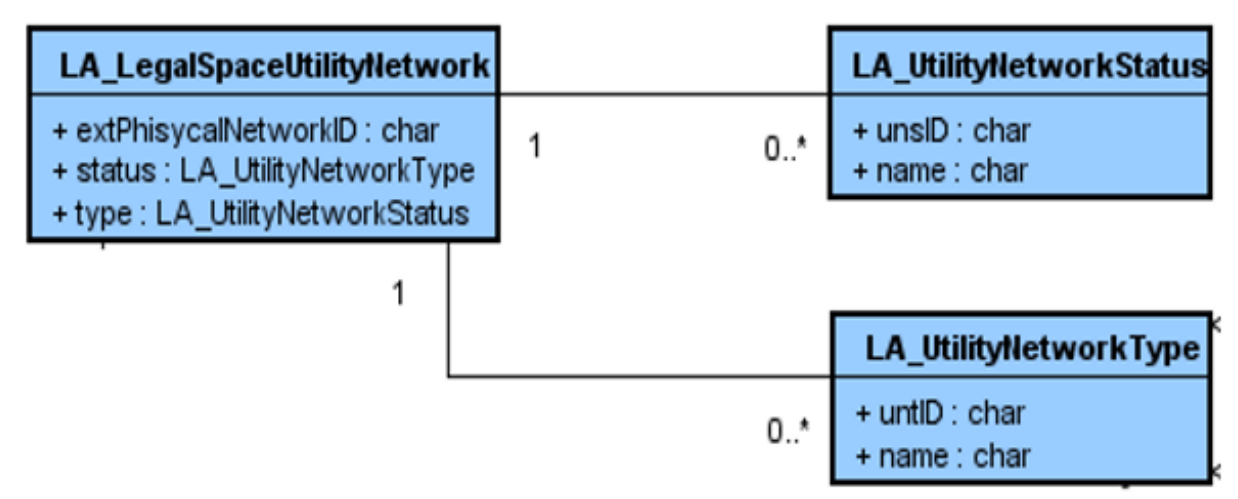

Figure 4: LA_LegalSpaceUtilityNetwork Class.

The attributes of the service network include: extPhysicalNetworkUnitID - as network identifier; status network status; and type - network service type. Relating to the analysis model, we have:

1. extPhysicalNetworkUnitID - hydrometer identifier;

2. status - Inactive, proposed, abandoned, removed, active;

3. type - Water supply network (drinking, raw, treated).

In total, the network structure consists of nineteen layers, composed by the elements that comprise the network and the information related to the control of water supply. Each layer is associated with an attribute table, which describes the elements that constitute it.

Figure 5 shows the inclusion of three of the nineteen layers in the format of classes belonging to the utility network package. These classes were chosen because of their direct relation with the connection of the water network itself. The class RA_RedeAgua is composed by the information referring to the pipeline that conducts the water to the locality; RA_Ramal connects the network to the client; and "RA_Hidrometro" measures and records the volume of water consumed by the customer. 


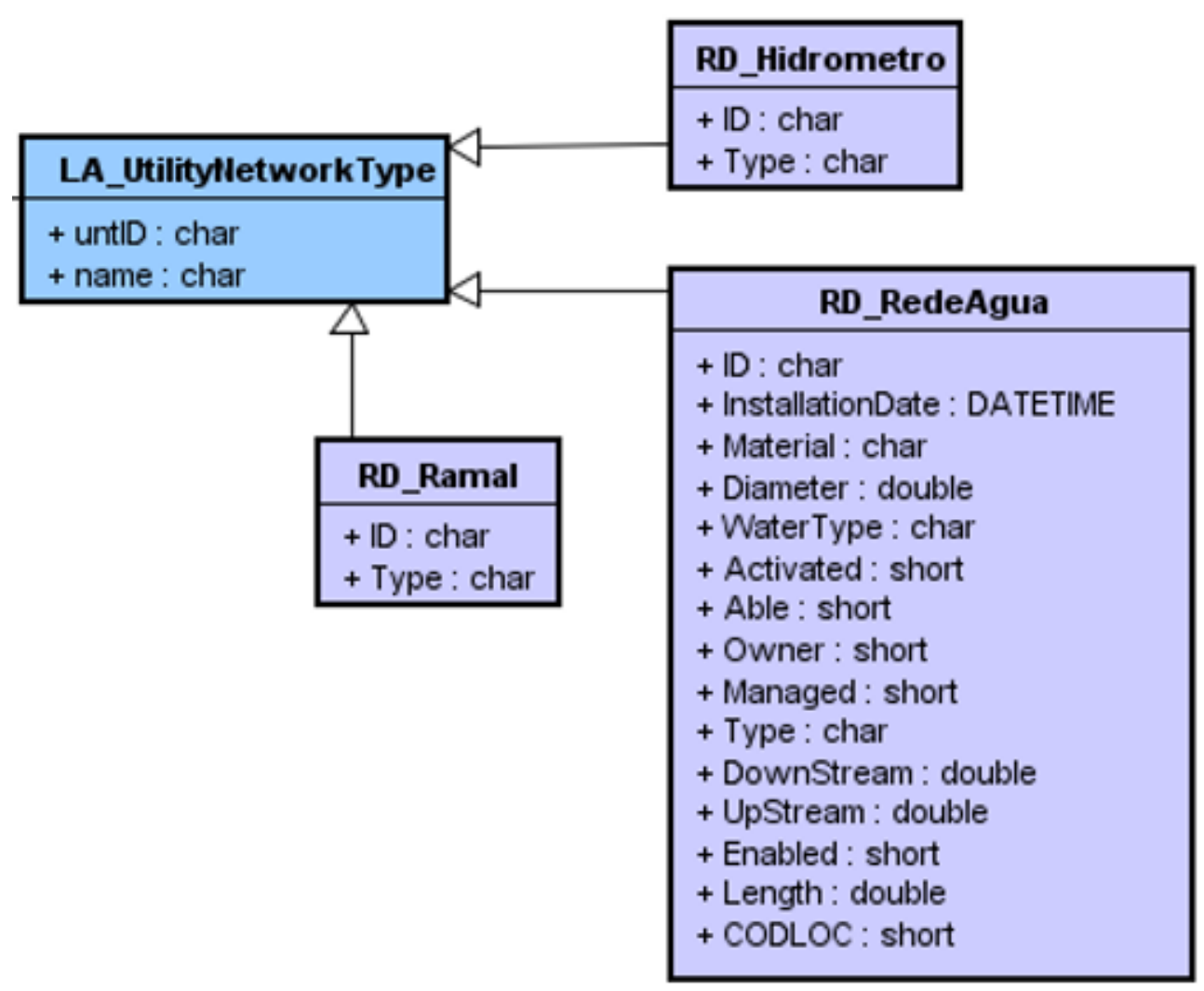

Figure 5: Specific Classes of water supply network

For the modeling of these classes an identification prefix of the initials of the words "Network" and "Water" was adopted in their name in order to differentiate it from other LADM classes, which are represented by "LA" prefix. The assigned color followed the pattern of the package from which it belongs, adopting a lighter shade of blue. Thus, the following classes were added: RA_RedeAgua; RA_Ramal and RA_Hidrômetro.

The RA_RedeAgua class attributes were included in the database content provided by COMPESA, suitable for model formatting.

The data regarding the attributes of the RA_Ramal and RA_Hidrômetro class were simulated due to the impossibility of the assignment of personal data from clients, which does not compromise the result of the modeling.

\subsection{Implementation of the Physical Model}

The physical model was elaborate after completing the conceptual modeling of the COMPESA water supply network within the standards of the LADM, which proves the feasibility of the project applied to the concessionaire network.

To implement the physical model from a conceptual model based on a UML diagram, it is necessary to generate the executed modeling script. Tests carried out by Cumbe (2016) and Costa (2016) found that the Astah Community software does not allow this export, so it was necessary to migrate UML modeling to other software that would be able to perform this action. Through research and testing, it was possible to select the DBDesigner software, which presented an easy to understand and manipulate interface, in addition to allowing a direct connection with Postgre / PostGIS - QGIS, free and open-source software used in the implementation phase.

DBDesigner is a CASE (Computer-Aided Software Engineering) tool developed by Fabulous Force Database 
Tools. This tool is free and available under the GNU General Public License (GLP), allowing visual data modeling. This software enables the generation of the project modeling and implementation and allows its connection to a database for synchronization.

The interaction between the modeling and the DBMS took place through PostgreSQL. The use of the software pgAdmin 4, with PostgreSQL (version 9.6) allowed executing the script exported from DBDesigner. In addition, foreign keys (FK) and primary keys (PK) were generated automatically through the relationships created within the physical modeling software. This did not generate any problems during the implementation phase, guaranteed the implementation of the model and confirmed the practicality of this process.

The implementation was achieved using the PostgreSQL database system and the PostGIS spatial extension. PostgreSQL is used as a DBMS and PostGIS as a geographical extension. Its activation enables the database management system PostgreSQL and stores geometric information of the cadastre, it makes an integrated management possible using the association of QGIS to PostgreSQL / PostGIS.

\section{Results and Discussion}

The compatibility between the LADM and the implementation of the water supply network data provided by COMPESA is characterized by the description of the packages and classes developed in the physical model. The structure of the LA_Party package followed the model provided by the LADM standard by aggregating the pertinent information to its correspondent within the case study database.

Figure 6 illustrates the physical model result of the LA_Party class.

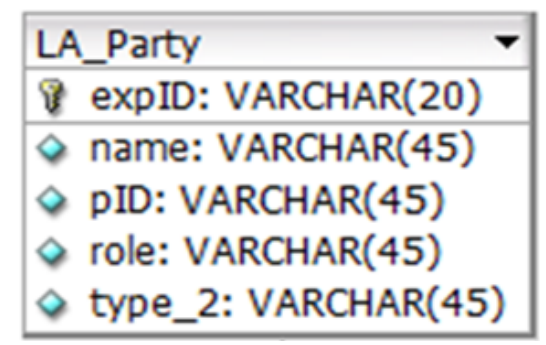

Figure 6: Physical modeling of the LA_Party class

The exPID identifier is characterized by the customer cadastre number, of varchar format (20), since it consists of 20 characters.

- exPID: $00000000.000 / 0000-0$

The other attributes of the class are characterized as it follows:

- name: Maria José de Jesus;

- pID: 000.000.000-00 (CPF) ou 00.000.000/0000-00 (CNPJ);

- role: José Maria de Jesus;

- type: Individual.

This class consists only of descriptive data. After the model implementation, the class receives the table format within the geoprocessing program. 
The Rigth, Responsibility and Restriction (RRR) network-related package is described below, as shown in Figure 7.

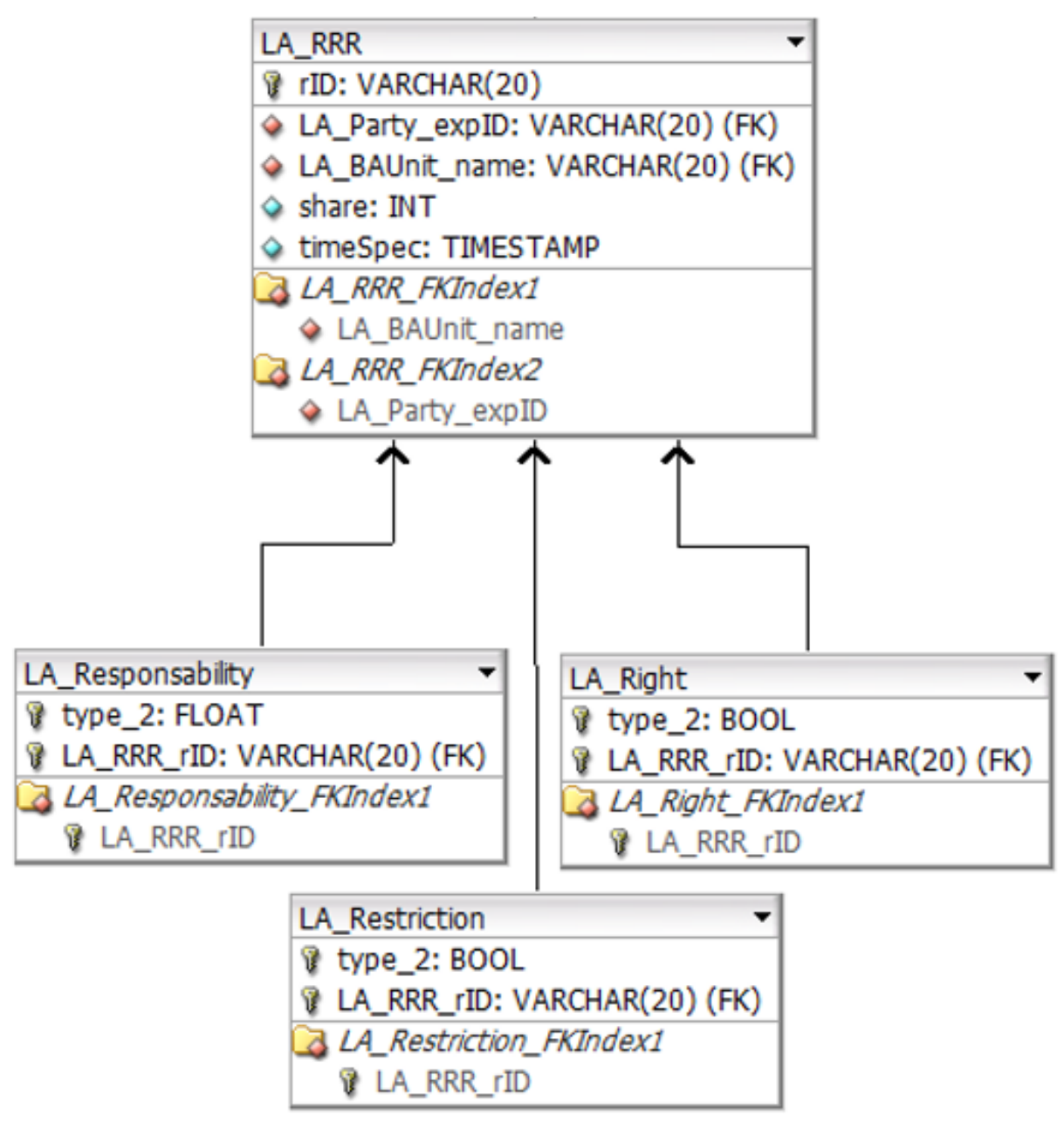

Figure 7: Physical modeling of class LA_RRR.

The attributes of the classes specify the agents acting in each particular case, as the right to drinking water access and the responsibility to maintain the rate of water supply by the service up with your payment due.

The LA_Responsibility class indicates the invoice payment amount, for example: 27.89 . And it is linked to the foreign key (FK) that expresses its relationship with the parent class LA_RRR.

LA_Right points out the customer's right in relation to the service provided by the company, the water. And it informs if the user has access (or not) to the water supply, processes directly related to the responsibility of payment of the water bill issued monthly by the company that provides the service. The class is fed by the data type BOOL (Boolean).

- Type_2: Yes or No.

Like the LA_Right class, the LA_Restriction class is of Boolean type, and tells whether the connection is active or not. The function may be deactivated if the supply has been interrupted due to lack of compliance with the responsibility assigned to it.

In this section, the RRRs directly associated to the case study of this research were clarified. However, considering the different possibilities of applying the LADM standard it's observed that the rights, restrictions and responsibilities related to the water distribution network may be extended to other examples such as the laying 
restrictions of the pipes indicated in NBR 12.266: 92 and the responsibility of maintaining the quality of water distributed to the population.

The development of the LA_SpatialUnit package configures the insertion of the geometry into the modeling, characterizing the spatial unit related to the other classes.

The modeling process of this class was distinguished by the characteristic of their relationships, since the core unit of the model is the water network (represented by lines), but the crucial point of the relationship between classes is constituted by the point that indicates the materialization of the hydrometer, instrument that informs the user's water consumption.

This step differs from the other models used by Cumbe (2016), Costa (2016), Frederico (2014) and Santos (2012), once all of them had the parcel as their starting point. The parcel in the case of study of this research is represented by the property to which a water connection is assigned although it is not the smallest unit cadastral, this one being identified by the hydrometer.

The LA_SpatialUnit class has two associated classes: LA_SpatialUnitGroup and LA_BoundaryFaceString.

- LA_SpatialUnitGroup represents the groups of spatial units, such as districts, census tracts, districts and supply sectors.

- LA_BoundaryFaceString simulates the property.

Associated with this class, the LA_LegalSpaceUtilityNetwork class is also presented along with its specifications: LA_UtilityNetworkStatus and LA_UtilityNetworkType.

LA_UtilityNetworkStatus informs the network situation: inactive, proposed, abandoned, removed, or active.

- LA_UtilityNetworkType indicates whether the network is of raw, potable or treated water;

The association between these classes is shown in Figure 8 .

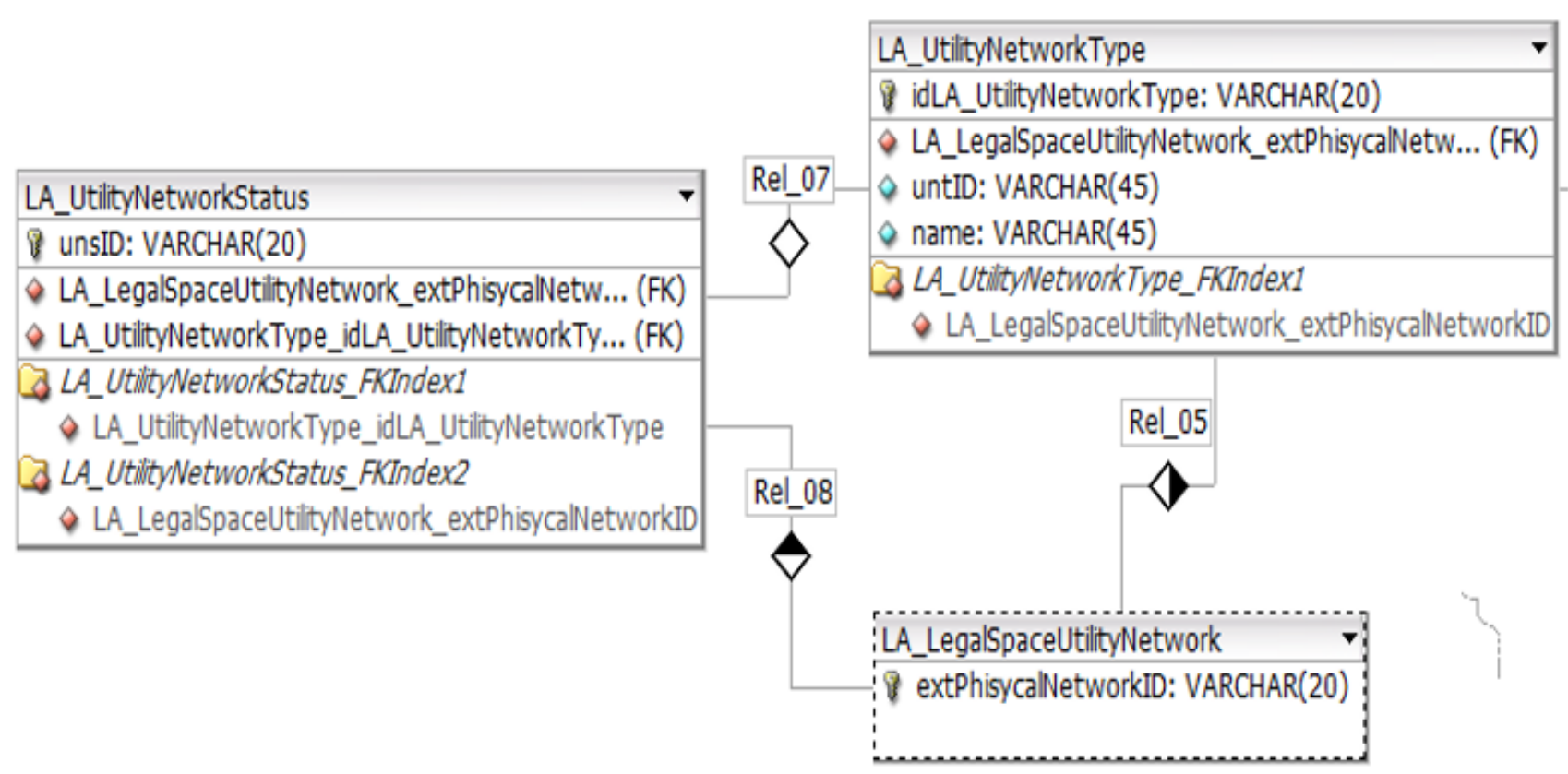

Figure 8: Physical modeling of the LA_LegalUtilityNetwork class

The classes that specifically characterize the water distribution network within the database of the study case used in this research were associated to the class LA_UtilityNetworkType, because they configure a type of network taken as an example: the water distribution network to the user. 
To make the model closer to reality, three specific classes were associated: RA_RedeAgua; RA_Ramal and RA_Hidrômetro. These classes were added to the model pre-determined by the standard, since it allows the configuration of the modeling according to the particularities of each cadastre.

1. The RA_Ramal class is represented by the line that leads the water to the client's property, connected to the water network pipe. These are associated with the LA_Hidrômetro class, through the foreign key link (FK);

2. LA_Hidrômetro is point type, characterized by the apparatus that measures the water consumption;

3. The LA_RedeAgua class contains information such as:

- Material: type of pipe material (ex: PVC, cast iron (FOFO), etc.);

- UpStream: height of the upper tube generatrix (ex: 1,00m below ground);

- DownStream): height of the bottom of the tube (eg $1.30 \mathrm{~m}$ below ground);

- This class is related to the other classes, since they are connected geometrically.

The LA_Point class receives the point geometry, directly related to the smallest unit cadastral in the model: the hydrometer.

The final stage of the project is characterized by the implementation phase of the physical model. The conceptual model built on the Astah Community software was transformed into a physical model using DBDesigner software. This procedure facilitated the implementation process, since DBDesigner allows the generation of a script, making it executable in pgAdmin 4, with the use of the PostgreSQL database.

With the established connection between PostgreSQL and PostGIS, it was possible to consolidate the implementation from QGIS software. This process enabled integrated management, where the property geometry was corrected in QGIS and its PostgreSQL-managed history.

The visualization of the implemented classes is presented in figure 09, where they can be identified in the format of tables within QGIS 2.8.1 Wien.

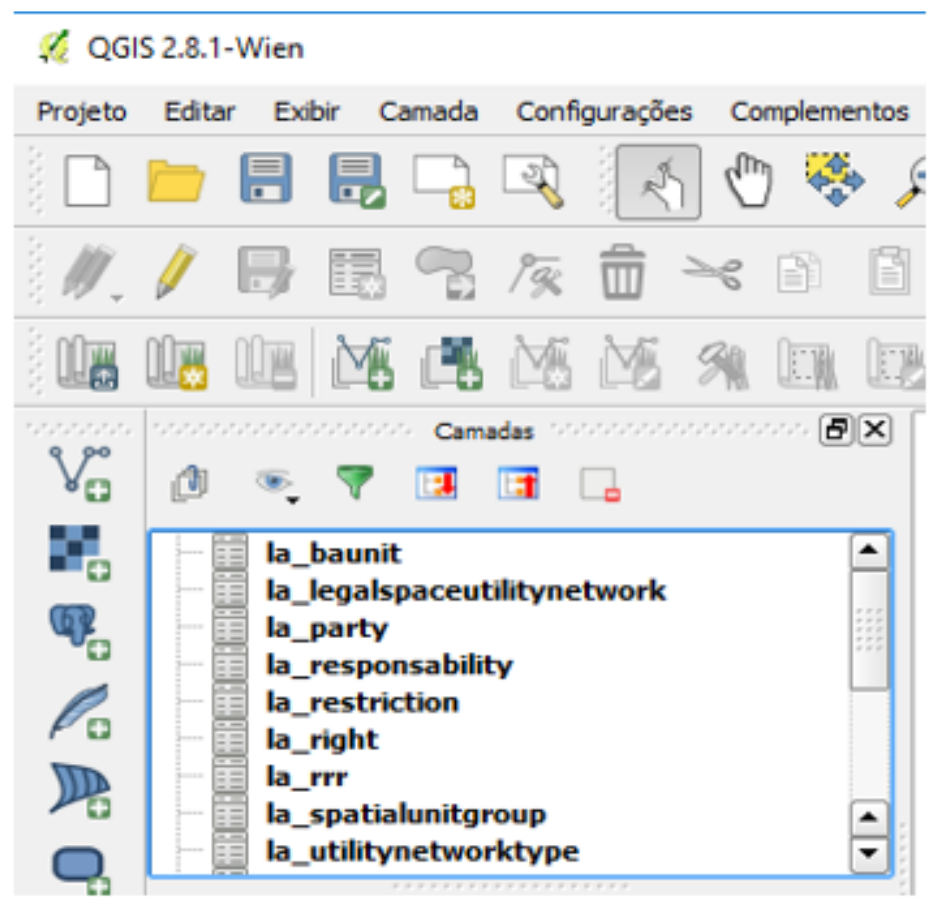

Figure 9: Visualization of classes implemented in QGIS 


\section{Conclusions}

This research proposal aimed to test the application of LADM standards, determined by ISO 19152, to the modeling of subsurface utility networks. As this is a subject still under-explored by the scientific community the results are important to demonstrate the feasibility of this application.

During the conceptual modeling stage, specific characteristics of the system were identified, such as the cadastral unit, the hydrometer, which differs from the traditional land cadastre unit, the parcel. Although the application has been restricted to a case study of the cadastre of water utility networks, it was possible to identify and characterize elements applicable to similar systems, which are characterized by facilities below the earth's surface.

The methodology and the software used in the conceptual and physical modeling stages were satisfactory and allowed the obtaining of results that confirm the suitability of the LADM to the modeling of subsurface utility networks. The flexibility of the model, for example, allowed the creation of classes RA_RedeAgua, RA_Ramal and RA_Hidrometro specifically for this type of $\mathrm{c}$ and that are not part of the basic classes proposed in ISO 19152.

\section{AUTHOR'S CONTRIBUTION}

Conceptualization: Silva, W. O. and Carneiro, A.F.T.

Data collect: Silva, W. O.

Modeling and Implementation: Silva, W. O.

Preparation: Silva, W. O. and Carneiro, A.F.T.

Review and supervision: Carneiro, A.F.T.

Discussion of results: Silva, W. O.

Final review: Silva, W. O. and Carneiro, A.F.T.

\section{REFERENCES}

ASSOCIAÇÃO BRASILEIRA DE NORMAS TECNICAS. NBR 12.218: Projeto de rede de distribuição de água para abastecimento público - Procedimento. Rio de Janeiro, 1994.

NBR 12.266: Projeto e execução de valas para assentamento de tubulação de água, esgoto ou drenagem urbana. Rio de Janeiro, 1992a.

. NBR 12.586: Cadastro de Sistema de abastecimento de água - Procedimento. Rio de Janeiro, 1992b.

BALOGUN, A. L. MATORI, A.N. and LAWAL, D. U. Geovisualization of Sub-surface Pipelines: A 3D Approach. Published by Canadian Center of Science and Education. <www.ccsenet.org/mas> Modern Applied Science. Vol. 5, №. 4. August 2011.

CÁMARA, M. A. U. BALBOA, J. L. G. and ARIZA LÓPEZ, F. J. Análisis de da Propuesta ISO 19152 (Land Administration Domain Model). Primer Congreso Internacional de Catastro Unificado y Multipropósito. Universidad de Jaén, España, 16 - 18 de junio, 2010.

COSTA, T. S. P. Uma Proposta de Modelagem de Cadastro 3D De Edifícios com Base na ISO 19152 (LADM). Dissertação (Mestrado) - Universidade Federal de Pernambuco. CTG. Programa de Pós-Graduação em Ciências Geodésicas e 
Tecnologias da Geoinformação, 2016.

CUMBE, R. A. Modelo de Implementação de Cadastros Territoriais Multifinalitários Urbanos em Moçambique. Dissertação (Mestrado) - Universidade Federal de Pernambuco. CTG. Programa de Pós-graduação em Ciências Geodésicas e Tecnologias da Geoinformação, 2016.

DÖNER, F. et al. Solutions for 4D cadastre - with a case study on utility networks. International Journal of Geographical Information Science Vol. 25, No. 7, July 2011, 1173-1189.

DU, Y. and ZLATANOVA, S. An approach for 3D visualization of pipelines. Delft University of Technology, Delft, The Netherlands. 2011. <http://www.gdmc.nl/3dcadastres/literature/>

FREDERICO, L. N. S. Modelagem de Cadastro Territorial de Bens Imóveis da União de Acordo com a LADM ISO/FDIS 19152:2012. Dissertação (Mestrado) - Universidade Federal de Pernambuco. CTG. Programa de Pós-Graduação em Ciências Geodésicas e Tecnologias da Geoinformação, 2014.

GUEDES, Gilleanes T. A. UML 2: uma abordagem prática. São Paulo: Novatec, 2011.

GUERRERO, J. ZLATANOVA, S. and MEIJERS, M. 3D Visualisation of Underground Pipelines: Best Strategy for 3D Scene Creation. ISPRS Annals of the Photogrammetry, Remote Sensing and Spatial Information Sciences, Volume II-2/W1, ISPRS 8th 3DGeolnfo Conference \& WG II/2 Workshop, 27 - 29 Istanbul - Turkey, November 2013.

HASHIM, M. WEI, J. S.; and MARGHANY, M. Subsurface Utility Mapping for Underground Cadastral Infrastructure. 31st Asian Conference on Remote Sensing 2010 (ACRS 2010). 1-5 November 2010, Hanoi, Vietnam. Volume 2, 2010, pages 1200-1206.

ISO/FDIS/TC211 (2012). ISO/TC 211 Geographic Information - Land Administration Domain Model (LADM). ISO/ FDIS 19152 (Final Draft International Standard).

LEMMEN, C. A Domain Model for Land Administration. Publications on Geodesy - 78. NCG - Nederlandse Commissie voor Geodesie. Delft, August 2012.

LEMMEN, C. and Van OOSTEROM, P. The Land Administration Domain Model Standard. 5th Land Administration Domain Model Workshop 24-25 September 2013, Kuala Lumpur, Malaysia.

LEMMEN, C.; Van OOSTEROM, P.; BENNET, R. The Land Administration Domain Model. Land Use Policy, v.49, 2015, p535-545. https://doi.org/10.1016/j.landusepol.2015.01.014

PAULSSON, J.; PAASCH, J. The Land Administration Domain Model - a Literature Survey. Land Use Policy, v.49, 2015, p546-551. https://doi.org/10.1016/j.landusepol.2015.08.008

POULIOT, J. CUISSART, R. and BORDIN, P. Cadastral mapping for underground networks: A preliminary analysis of user needs. 27th International Cartographic Conference. 16th General Assembly. Maps Connecting the World. August 23-28, 2015. Rio de Janeiro, Brazil.

POULIOT, J. and GIRARD, P. 3D Cadastre: With or Without Subsurface Utility Network? 5th International FIG 3D Cadastre Workshop. Athens - Greece, 18-20 October 2016 .

RADULOVIĆ, A. et al. 2019. LADM Based Utility Network Cadastre in Serbia. ISPRS Int. J. Geo-Inf. 8, no. 5: 206.

ROTATIONAL SOFTWARE CORPORATION. UML - Unified Modeling Language. Rotational Software Corporation, 1997. https://www.ibm.com/cloud/devops

SANTOS, J. C. Análise da aplicação do modelo de domínio de conhecimento em administração territorial (LADM) ao cadastro territorial urbano brasileiro - estudo de caso para o município de Arapiraca - AL. Dissertação (Mestrado) Universidade Federal de Pernambuco. CTG. Programa de Pós-Graduação em Ciências Geodésicas e Tecnologias da Geoinformação, 2012.

SILVA, W. O. Proposta de um modelo de cadastro de redes de abastecimento d'água, de acordo com a ISO/FDIS 19152. Dissertação (Mestrado) - Universidade Federal de Pernambuco. CTG. Programa de Pós-Graduação em Ciências Geodésicas e Tecnologias da Geoinformação, 2017.

YAN, J. et al. The LADM-Based 3D Underground Utility Mapping: Case Study In Singapore. Int. Arch. Photogramm. Remote Sens. Spatial Inf. Sci., XLII-4/W15, 117-122, https://doi.org/10.5194/isprs-archives-XLII-4-W15-117-2019, 2019. 